\title{
Correlation And Integration Between Faith, Knowledge And Behavior
}

\author{
Arip Surpi Sitompul \\ \{sitompul.aripsurpi@gmail.com\} \\ IAKN Tarutung, Medan, Indonesia
}

\begin{abstract}
In the reality of everyday life, scholarship is not a guarantee of the quality of life of a person, the high level of knowledge does not indicate a high level of faith, the high level of knowledge and faith does not show the high level of behavior in accordance with the demands of the religion that someone believes. The relationship of knowledge, faith and behavior, refers to the statement of the famous theologian Francis Chaeffer, who said, "I do what I think, and I think what I belief". The theological basis of the three components of the discussion; correlation and integration based on the Bible. Faith is progressive or growing because of doing (do) virtue and knowledge grows because of fellowship and the introduction of Christ Jesus. Knowledge is progressive and its growth is due to the learning process. Religious knowledge with religious experience is like two sides of a unified coin, that is true religious life.
\end{abstract}

Keywords: faith, knowledge, behavior

\section{Introduction}

The topic of this study is entitled Correlation and Integration Between Belief, Knowledge and Behavior. According to UNESCO there are four pillars of education, namely Learning to know, learning to do, learning to be, and learning to live together this concept is very biblical, because religious education is not just a transfer of knowledge but a spiritual transformation that leads to self-actualization in accordance with God's purpose for His chosen people. So, learning is not only from not knowing to knowing, but how that knowledge guides and helps a person to make himself what he is in harmony with God's purpose for that person, and to make someone meaningful, useful, beneficial to others. All of which lead to the glory of the name of God in and through his life.

Indeed, the high level of knowledge should be directly proportional to the high level of faith, and the high level of faith is directly proportional to the high level of behavior in accordance with the knowledge and religious beliefs. But the reality in everyday life, scholarship is not a guarantee of the quality of life of a person, the high level of knowledge does not show a high level of faith, the high level of knowledge and faith does not show the high behavior in accordance with the demands of the religion that someone believes.

The occurrence of das sain and solen against what is supposed to be in reality is a problem that raises questions, why is that? How is the correlation and integration and synchronization between faith, knowledge and behavior that is in accordance with their knowledge and religious beliefs? This is the problem formulation in this study. 


\section{Theoretical Study}

This theoretical study is focused on three components of development or growth psychology theory. The first theory of development of faith by James W. Fowler. Both Thorndike's theories of connectionism about behavior result from learning. The three psychological theories of Jean Piaget's development of the development of knowledge or understanding.

First. The inventor of the theory of growth in faith is from the most famous researcher, James W. Fowler. Fowler has focused his career academically to study the nature of faith and its growth. Theologically, Fowler's theory is based on the work of H. Richard Niebuhr, Paul Tilich and Wilfred Cantwell Smith. Fowler found that there are six stages in the growth of faith.

The initial stage from birth to 2 years: Primal - Undifferentiated Faith (faith-based without difference) Faith in this case is formed by the experience of affection and care for parents and other adults. Here the seed of faith is sown. (This stage is not included in the six stages according to Fowler, because in the early days this was the planting of seeds of faith and not including growth.

Stage first 3-7 years: Intuitive-Projective Faith (intuition / projective voice). Imagination arises through stories, signs and other symbols. Regarding perceptions and feelings, imagination creates a strong picture of faith that continues throughout the lifetime. During this stage, emotions become morally clear. A child's understanding of God shapes and is influenced by experiences with parents and other adults whose emotional connection has been established.

The second stage is $8-11$ years: Mythical-Literal Faith (literal tales). Here, a child will begin to use stories, beliefs and practice them in his faith community. A child is able to distinguish between reality and fantasy. At this stage a child sees God anthropomorphically: wrong or right behavior seen through the lens of consequences: true is everything that is given an award or prize, while wrong is whatever is given a punishment.

The third stage is 12-22 years: Synthetic-Conventional Faith (Synthetic-conventional / conventional faith). Because official thinking is cognitive activity from growth is known, teens are able to use abstract ideas to determine the meaning of life. Mutual perspectivetaking, an ability to see things the way other people see them, also see ourselves as others see us. Faith is also formed, honed by the identity that is feared. There are additions, namely hunger for a personal relationship with God who knows, accepts and strengthens.

The fourth stage (early adulthood): Individuative-Reflective Faith (individuativereflected faith). This stage involves, first of all, a test of thought, including questions, which leads to the re-sharpening of the initial understanding of faith. Second, this involves how to lead the lives of others. In this stage individual responsibility becomes very prominent. There is a gap between individual responsibility and Faith that is highlighted by someone in the previous stage. Finally, there are debates between relativism and absolute. This estrangement was finally resolved when the ability to make criticism was tested in divinity that had become clear.

The fifth stage (middle to upper adult): Conjunctive Faith. At this stage, there is a sense of having to come to the surface of the deep relationship with reality shown by the symbols. A very strong desire to accompany others in clarifying their own faith.

Sixth stage (final adult): Universalising Faith (Universal Faith). A feeling rooted firmly grows in Transcendent, "the basic condition of existence," or in God. An ability emerges perspective in allowing oneself without judging himself. There is a struggle to live with ideal 
love and justice with people in a defensible manner. There is openness that grows toward truth in all types of faith.

Second. One of the Behaviorist figures is Edward Lee Thorndike (1874-1949), with his Theory of Connectionism. According to Thorndike, learning is the event of the formation of associations between events called stimulus (S) with response (R). From the hungry cat experiment that is inserted into a puzzle box, it produces three learning laws related to behavior, namely:

1. Law of readiness, namely the more ready an organism gets a change in behavior, the implementation of such behavior will lead to individual satisfaction so that the association tends to be strengthened.

2. Law of Exercise (law of exercise), namely the more frequent behavior is repeated / trained (used), then the association will be stronger. The principle of law of exercise is the connection between conditions (which are stimulants) and action will be stronger because of the exercises, but will weaken if the connection between the two is not continued or stopped. The principle shows that the main principle in learning is repetition.

3. Law of effect (law of effect), namely the relationship of stimulus responses tend to be strengthened if the consequences are pleasant and tend to be weakened if the consequences are not satisfactory.

Third. Cognitive Learning Theory according to Piaget about aspects of cognitive development aspects, namely stage (1) motor sensory (2) pre-operational (3) operational concrete and (4) formal operational. According to Piaget, learning will be more successful if it is adjusted to the stages of cognitive development of students. Language and ways of thinking are different from adults. Therefore the teacher teaches by using language that is in accordance with the child's way of thinking. A person's knowledge develops according to his level of intelligence and experience. The development of knowledge is the result of association from the meaning of something. Thus this association theory or cognitive theory concludes that intellectual development or knowledge of a person is influenced by the development of the organism and the maturity of a person is directly proportional to physical maturity.

\section{Thinking Framework and Hypothesis}

Based on the three theoretical foundations above, four frameworks of thinking and hypothesis were born. First, based on James W. Fowler's theory, one's faith grows according to the physical and psychological stages of growth, so the hypothesis: the more mature a person is, the higher his faith. Second, based on the Edward Lee Thorndike Theory, a person's behavior grows when stimulated, trained and satisfied through the learning process, then the hypothesis is: the higher the education or the more often someone learns, the higher the service or the more skilled in doing it. Third, based on Jean Piaget's theory, a person's knowledge grows along with the growth of the nervous system in an organism according to its development stage, so the hypothesis: the more mature a person is, the more knowledgeable that person is. Fourth, because the experts above underlie their research based on psychological theory of development where the stages of development of faith, science and behavior are based on the development of a person starting from the phase of birth, birth, adolescence and adulthood, adult post, then the hypothesis formulation is integrated, the higher one's knowledge, the higher the faith and the higher one's faith, the higher the service. 


\section{Analysis}

Faith means loyalty and trust (loyalty \& trust), which are expressed in several fields. First, there is devotion to ideas or people who are very meaningful to us. This is described as the core value of 'Core Values', something that evokes our love and devotion and for that applies the structure of power in our entire life to what is contained in it, God, along with other core values, falls into this category. there is loyalty at the center of power that gives us a feeling of security. Everyone serves the "main story" that gives direction and hope in life.

The nature and quality of faith is, first: paying attention to its relationship, its appearance, in the triad pattern. The first part in the triad is the relationship with the "core value". The second part of the triad is yourself, while the third part is someone else. Faith is not a private matter, an individual problem. Relations with others, while at the same time having mutual relations with a core value, forming a triad pattern.

Secondly, faith is seen at the outset that faith leads to existence and does (cf. James 2:17, "... faith without works is essentially dead ..."). Knowledge is not something that is only tucked into memory that can be called at any time when needed. But it is more than just knowing aspects of faith whose meaning must be done or must be acted upon. This needs to be experienced by forming who we are and what we do. Faith is active not static. He holds that knowledge grows through interaction with people, ideas and experiences.

The relationship of knowledge, faith and behavior, refers to the statement of the famous theologian Francis Chaeffer, who said, "I do what I think, and I think what I belief". That is, I do what I think and I think about what I believe. This statement indicates three aspects of religious life, namely, "do, think, belief". The three aspects of religious life are related to one another. This statement also implies that if the right action starts from the right mind and the right mind is based on the right belief, and vice versa if the belief is wrong it will lead someone to think wrong and the wrong mind will produce the wrong action.

The theological basis of the three components of the discussion; correlation and integration based on the Bible. Faith is progressive or growing because of doing (do) virtue and knowledge grows because of fellowship and the introduction of Christ Jesus. Doing is an expression of belief, so doing and belief are correlated and integrated (Ps. 37: 3 "Believe in God and do good"). Trust is placed on the basis of what is known and there is no belief without knowledge (2 Tim 1:12 "... I know who I trust").

Knowledge is progressive and its growth is due to the learning process (Dan 12: 4 "... The Bible ... many people will investigate it and knowledge will increase). Knowledge must be implemented for good. Bible data as a reference to faith, knowledge and fruit or doing, concludes as follows. First, faith, knowledge and fruit are an integrated unit in the life of God's people. The relationship is interrelated and has a causal relationship. Second, faith, knowledge and fruitfulness are progressive or growing, but the growth is not due to physical or psychological growth in accordance with the stages or phases of the growth of the developmental psychology review but because of the consistency of obedience to what is believed and done as a consequence of his knowledge. Third, the high level of faith, knowledge and dedication of a person is in line with the high obedience and submission of someone to what God wants from everyone (Romans 6: 1-8: 17 and Gal. 5: 16-26). 


\section{Conclusion}

The hypothesis is rejected on the grounds of: 1) The height of a person's faith is not determined by the person's age level. There are adults but their faith does not show maturity. 2) The height of faith is not necessarily because of the high level of knowledge (children are not more knowledgeable than adults, but the submission of children to what they believe is much higher than that of people who have high knowledge), because children have a high submission to higher sovereignty as proof of his faith. 3) High knowledge is not necessarily high in service, because there are factors that make it possible for him to devote his knowledge to high, namely laziness, egocentric, sarcastic. 4) High knowledge is not necessarily high in faith, because if knowledge is oriented to logic and rationalism is counterproductive to faith. 5) High dedication not because of high knowledge, because it can be caused, high faith, oriented to obedience to God's call. 6) The level of service is not necessarily because of the high level of faith, because it can occur because the motivation of service is not oriented to obedience but because of greed.

Hypotesis is accepted, if: 1) The high level of knowledge is obtained through learning and godly experience. The closer a person is through fellowship and obedience to God, the higher is his knowledge. 2) The high level of one's faith is acquired through learning and godly experience, and through obedience to doing God's will. The high level of behavior that is in harmony with God's will is obtained because of faith and obedience to God's will. Obedience to God which is shown through living behavior as a result of self-denial of the desires of the flesh (sarkatikos), and following the will of the Spirit (pneumatikos), that's where growing knowledge of God and experience of god (faith). The high level of knowledge, faith and dedication is to give meaning to the process of growth through the stages that go through to a high phase, not instant. The correlation and synchronization between faith, knowledge and fruitfulness is realized with consistency keywords, as shown in the picture below.

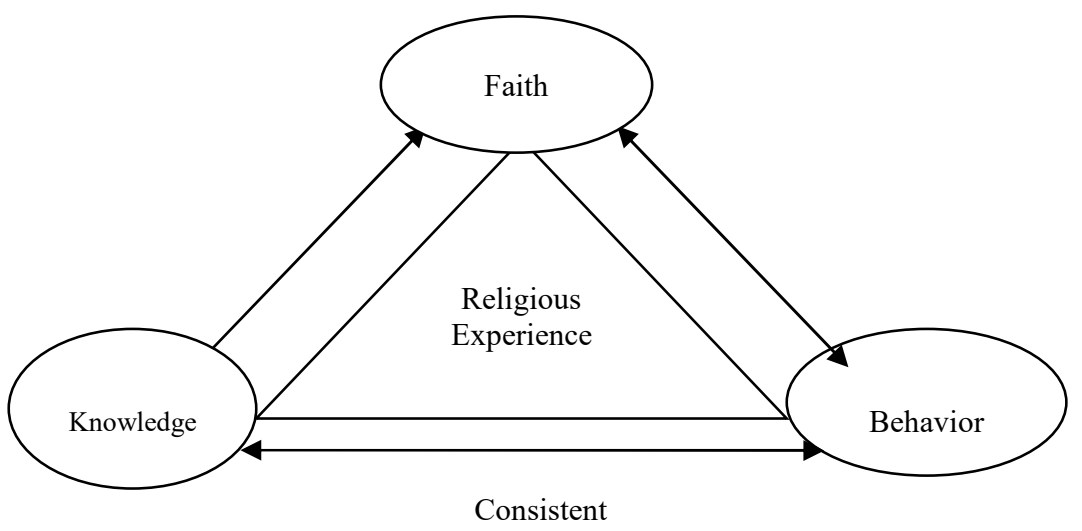

Religious knowledge with religious experience is like two sides of a unified coin, that is true religious life. Religious knowledge contains aspects of faith and knowledge. Religious experience contains aspects of faith and behavior. Belief is a binder of knowledge and behavior. Behave from what you believe and know. Knowledge of what is believed to be the reality of life. This is what is called prime theology and secondary theology. 


\section{References}

[1] Hurlock B. Elizabeth. Psikologi Perkembangan : Suatu Pendekatan Sepanjang Rentang Kehidupan. Jakarta: Erlangga, 2004.

[2] Iswara Rintis. Teologi Untuk Semua Orang. Bandung : Lembaga Literatur Babtis, 2010

[3] James $W$. Fowler. Stage of Faith: The Psychology of Human Development and the Quest for Meaning. San Fransisco: Harper and Row, 1981. Life. Nashville: Abington, 1996.

Faithful Change: The Personal and Public Challenges of Postmodern Latter Lif. ed. Bill Puka et al. New York: Garland,1994.

[6] Stages in Faith Consciousness : In Religious Development in Childhood and Adolescence. ed. Fritz Koser and W. George Scarlett. San Francisco: Jossey - Bass, 1991

[7] . Faith and the Structuring of Meaning : In Toward Moral and Religious Maturity, ed. Chritiane Brusselmans and James A. O'Donohoe. Morristown, NJ.:Silver Burdet, 1980.

[8] Winfred F.Hill. Theories of Learning. Terj. M.Khozin. Bandung : Nusa Media, 2009.

[9] Jeff Astley, Leslie J. Francis, Critical Perspectives on Christian Education: A Reader on the Aims, Principles and Philosophy of Christian Education, Leominster, Herefordshire Gracewing Publishing, 1994, pp. 246.

[10] Tyron Inbody, The Faith of the Christian Church: An Introduction to Theology. Grand Rapids, Michigan : Wm. B. Eerdmans Publishing, 2005, pp. 45. 